\title{
PENGEMBANGAN E-MATERI BERBASIS COURSELAB MATAPELAJARAN IPS POKOK BAHASAN MENGHARGAI JASA DAN PERANAN TOKOH PERJUANGAN DALAM MEMPERSIAPKAN KEMERDEKAAN INDONESIA KELAS V SDN TAPAK PANEKAN MAGETAN
}

\author{
H. Saiman * \\ Rini Apriyanty **
}

\begin{abstract}
E-matter that is structured science area information set for study that is presented in the form of electronic that make easy student to accessing matter that taught by teacher, so that easier student to study matter that given. Courselab ingredient composer's soft apparatus teaches multimedia to e-learning powerful and easy used. Courselab this be alternative that can be used teacher to learning ematter for student especially Class $V$. This research aims to detect feasibility e-matter study that developed based on validation result to be used in social science study at Class $V$ elementary school. Research method that used $R \& D . R \& D$ method that used to produce certain product, and test product effectiveness. This method is used to produce and test e-matter based on Courselab. Study media based on Courselab social science that developed proper used to support study social science main criticism appreciates service and struggle figure part in prepare Indonesia independence, because tested the feasibility by media expert and study matter expert with proper result.
\end{abstract}

Keywords: E-matter, Courselab

\begin{abstract}
Abstrak
E-Materi yaitu seperangkat informasi bidang ilmu yang terstruktur untuk pembelajaran yang disajikan dalam bentuk elektronik yang memudahkan siswa untuk mengakses materi yang diajarkan oleh guru, sehingga siswa lebih mudah untuk mempelajari materi yang diberikan. Courselab adalah piranti lunak penyusun bahan ajar multimedia untuk e-Learning yang powerful dan mudah digunakan. Courselab ini merupakan alternatif yang dapat digunakan guru untuk membelajarkan E-materi kepada siswa khususnya Kelas V. Penelitian ini bertujuan untuk mengetahui kelayakan E-Materi pembelajaran yang dikembangkan berdasarkan hasil validasi untuk digunakan dalam pembelajaran Ilmu Pengetahuan Sosial di sekolah dasar Kelas V. Metode penelitian yang digunakan adalah metode Penelitian dan
\end{abstract}

* H. Saiman adalah Dosen Program Studi PGSD FIP IKIP PGRI Madiun

** Rini Apriyanty adalah Mahasiswa Program Studi PGSD FIP IKIP PGRI Madiun 
Pengembangan. Penelitian dan pengembangan (research and development) adalah metode penelitian yang digunakan untuk menghasilkan produk tertentu, dan menguji keefektifan produk tersebut. Metode ini digunakan untuk menghasilkan dan menguji EMateri berbasis Courselab. Media pembelajaran berbasis Courselab matapelajaran IPS yang dikembangkan layak digunakan untuk mendukung pembelajaran matapelajaran IPS pokok bahasan menghargai jasa dan peranan tokoh perjuangan dalam mempersiapkan kemerdekaan indonesia, karena telah diuji kelayakannya oleh ahli media dan ahli materi pembelajaran dengan hasil layak.

\section{Kata Kunci: E-Materi, Courselab}

\section{A. PENDAHULUAN}

Demi memaksimalkan tercapainya tujuan pembelajaran perlu adanya perangkat yang mendukung jalannya proses pembelajaran. Perangkat tersebut disebut perangkat pembelajaran. Secara umum semua matapelajaran mempunyai perangkat pembelajaran, termasuk matapelajaran Ilmu Pengetahuan Sosial (IPS). Perangkat pembelajaran yang diperlukan dalam mengelola proses pembelajaran dapat berupa: silabus, rencana pelaksanakan pembelajaran, lembar kegiatan siswa, instrumen evaluasi atau tes hasil belajar, media pembelajaran serta buku ajar siswa. Saat ini guru cenderung kurang memperhatikan keseluruhan dari perangkat pembelajaran tersebut. Kadang ditemui guru hanya bergantung pada buku pegangan yang sudah ada. Akibatnya, siswa menjadi cenderung lebih malas dan cepat bosan dalam mengikuti pembelajaran di kelas.

Pendidikan IPS menekankan kepada kemampuan peserta didik dalam memahami bagaimana sebuah nilai muncul dan dilaksanakan dalam kehidupan bermasyarakat (Soebijantoro, 2011: 31). Guru dalam proses pembelajaran IPS selama ini masih terlihat kurang variatif dan kesulitan untuk menciptakan inovasi baru. Selain itu guru memiliki keterbatasan waktu untuk mengembangkan materi yang mudah untuk dipahami dan menarik siswa untuk mempelajari materi yang ada di dalamnya. Masalah lain yang muncul terkait dengan kurangnya buku teks yang dapat digunakan guru dalam sumber dan media pembelajaran umumnya masih bersifat umum, bahasanya sulit dipahami siswa, sehingga pemahaman siswa menjadi kurang dan siswa menjadi lebih cepat bosan.

Berdasarkan pengamatan yang dilakukannya terhadap sejumlah materi IPS yang beredar diperoleh suatu hasil bahwa materi pelajaran IPS yang beredar mutunya kurang, karena tidak menekankan pada materi yang akan dibahas melainkan buku tersebut mencakup semua materi dari Semester 1 sampai dengan Semester 2. Guru harus dapat mengorganisasikan materi dan menyajikan materi sesuai kebutuhan siswa mengembangkan materi agar siswa dapat lebih memahami apa yang yang akan dibahas atau diajarkan oleh guru. Hasil pengamatan di SDN Tapak Panekan Magetan, dalam proses pembelajaran, guru matapelajaran IPS cenderung masih menggunakan sumber belajar yang telah tersedia seperti bukubuku ajar yang telah beredar pada umumnya. Alasan guru menggunakan sumber pembelajaran tersebut dikarenakan bahwa sumber pembelajaran tersebut sudah siap pakai sehingga tinggal menggunakannya sebagai sumber belajar. Selain hal 
tersebut, sumber pembelajaran yang berbentuk buku ajar dapat digunakan dalam jangka waktu yang panjang. Dampak dari penggunaan sumber tersebut, dapat menyebabkan ketergantungan guru terhadap sumber yang sudah ada. Selain itu buku ajar yang beredar saat ini cakupan materinya masih terlalu luas. Oleh karena itu, penelitian ini menawarkan alternatif terhadap keterbatasan sumber belajar sehingga lebih menarik siswa untuk mempelajari materi yang diajarkan dengan menggunakan E-materi yang berbasis Courselab sesuai kebutuhan siswa dalam mengikuti matapelajaran IPS.

E-Materi yaitu seperangkat informasi bidang ilmu yang terstruktur untuk pembelajaran yang disajikan dalam bentuk elektronik yang memudahkan siswa untuk mengakses materi yang diajarkan oleh guru, sehingga siswa lebih mudah untuk mempelajari yang diberikan. E-Materi dapat berupa aset-aset yang terpisah dan disusun secara bermakna sehingga dapat diakses untuk memperkaya penjelasan agar pembelajar lebih memahami bagian yang diterangkan dalam sebuah buku ajar. Courselab adalah piranti lunak penyusun bahan ajar multimedia untuk e-Learning yang powerful dan mudah digunakan. CourseLab menawarkan lingkungan WYSIWYG (What You See Is What You Get) yang bebas dari pemrograman untuk menghasilkan bahan ajar interaktif yang dapat dipublikasikan di internet, Learning Management Systems (LMS), serta CD-ROM.

Bertolak dari penjelasan tersebut, E-materi pembelajaran IPS berbasis courselab untuk siswa Kelas $\mathrm{V}$ merupakan sebuah solusi untuk mengatasi berbagai masalah yang dihadapai oleh guru dalam pemakaian bahan ajar yang selama ini masih mengacu pada pokok bahasan yang sangat luas atau menggunakan bahan ajar pada umumnya. Materi yang ada dalam bahan ajar pada umumnya masih terlalu luas sehingga siswa sulit dalam memahami materi yang diberikan guru. Pada pengembangan E-materi IPS ini, diharapkan siswa kelas V akan lebih tertarik dan memahami konsep matapelajaran IPS sesuai dengan kebutuhannya. Produk berupa E-materi pembelajaran yang dikembangkan mempunyai spesifikasi: (1) E-materi yang berbasis CourseLab disajikan dalam bentuk elektronik, mencakup materi yang akan dibahas atau diajarkan kepada siswa; (2) kegiatan E-materi lebih mementingkan keaktifan siswa daripada guru (student centered); dan (3) materi yang dikembangkan adalah materi pelajaran IPS Kelas V. Selain itu materi yang ditampilkan dengan bentuk E-materi yang berisi seperti biografi penjuang beserta foto, hal yang diperjuangkan, berisi muatan yang dapat memberikan motivasi dan hanya mencakup materi yang akan dibahas.

\section{B. KAJIAN PUSTAKA}

1. Konsep E-Materi

E-Materi yaitu seperangkat informasi bidang ilmu yang terstruktur untuk pembelajaran dan disajikan dalam bentuk elektronik. Seperangkat informasi bidang ilmu yang terstruktur meliputi capaian pembelajaran (learning outcomes), beragam bentuk informasi (tekstual, gambar, audio, video, simulasi, multimedia), ruang lingkup informasi (matakuliah, topik, pokok bahasan), perangkat asesmen dan evaluasi. E-Materi dapat berupa aset-aset yang terpisah dan disusun secara bermakna sehingga dapat diakses untuk memperkaya penjelasan agar pembelajar lebih memahami bagian yang diterangkan dalam sebuah buku ajar. Aspek yang paling penting dalam E-Materi ini yaitu sarat dan padat dengan teknologi komunikasi dan perangkat lunak yang digunakan seharusnya berupa perangkat 
yang sudah umum digunakan oleh orang pada umumnya dan bebas diunduh tanpa biaya.

a. Prosedur Pengembangan E-Materi

Pengembangan E-Materi yang terdiri atas enam tahapan, yaitu: (1) tahap analisa; (2) tahap perancangan; (3) tahap pengembangan; (4) tahap penyampaian; (5) tahap evaluasi; dan (6) tahap pemeliharaan. Kedalaman masing-masing tahapan ini dapat disesuaikan dengan kepentingan pengembang E-Materi yang disesuaikan dengan tujuan penyajian E-Materi. Keenam tahapan ini memuat karakteristik unik dalam merealisasikan E-Materi berbasis objek pembelajaran. Analisis diawali dengan melakukan proses: (1) menentukan penyebab dari permasalahan berkaitan dengan hasil belajar atau kebutuhan untuk pengalaman belajar; (2) mencari penyelesaian yang dapat berupa media belajar, substansi materi, strategi pembelajaran, peningkatan motivasi, dan manajemen pembelajaran; dan (3) mendefinisikan kegiatan / tugas-tugas dan indikator hasil belajar yang hendak dicapai melalui penyelesaian tersebut. Pengembang konten perlu melakukan analisis granularity (keberbutiran) yang mana satu matapelajaran diurai ke dalam bentuk objek-objek lepasan yang lebih kecil melalui proses: (1) menganalisis kompetensi matapelajaran atau satu kurikulum dengan mempertimbangkan prinsip reuse dan repurpose sehingga dapat dijabarkan sebagai objek-objek lepasan (OP) yang sharable dan reusable; (2) menganalisis struktur kompetensi objek-objek lepasan (OP) dalam satu matapelajaran bahkan dalam satu kurikulum, sehingga objek-objek lepasan (OP) terhubung dalam struktur prasyarat, prosedural, pengelompokan atau gabungan; dan (3) menganalisis alternatif struktur kompetensi dalam satu matapelajaran bergantung pada entry beaviour matapelajaran tersebut.

Berdasarkan hasil analisis, tahap perancangan desain dilakukan melalui proses: (1) mendefinisikan objek lepasan (OP) pada setiap level; (2) mendefinisikan prasyarat dan kompetensi tiap objek lepasan (OP); (3) mendefinisikan relasi tiap objek lepasan (OP); (4) merancang metadata objek lepasan (OP); (5) merancang strategi pembelajaran objek lepasan (OP); (6) merancang media pembelajaran objek lepasan (OP); dan (7) menyelaraskan kompetensi, latihan, dan asesmen. Fase pengembangan dilaksanakan mengacu pada hasil desain yang mana perlu memperhatikan hal-hal: (1) mengembangkan eMateri dengan menerapkan reuse dan repurpose objek lepasan pada setiap level, serta menerapkan reuse dan repurpose objek informasi dan aset digital; (2) mengembangkan E-Materi menggunakan teknologi yang bersifat netral terhadap mode penyampaian (delivery); (3) mengembangkan E-Materi menggunakan teknologi yang bersifat independen terhadap perangkat yang digunakan untuk mengakses; dan (4) mengemas E-Materi mengikuti standar dan spesifikasi ePembelajaran.

Selanjutnya fase penyampaian, kegiatannya adalah mempersiapkan lingkungan pembelajaran atau sistem e-Pembelajaran yang mampu mendukung implementasi E-Materi untuk persiapan, pelaksanaan, dan pengawasan proses pembelajaran serta penilaian hasil belajar. Penyampaian E-Materi dapat diberikan dalam beragam format dokumen, misalkan: buku elektronik, buku cetak, berbasis web, atau dalam bentuk CD (compact disc). Disamping itu, e-Materi dapat disampaikan dalam beragam bentuk pembelajaran, yaitu: (1) pembelajaran 
mandiri; (2) pembelajaran jarak-jauh; (3) pembelajaran blended; dan (4) pembelajaran berbasis guru.

Pada model pengembangan e-Materi berorientasi objek pembelajaran, evaluasi dilakukan pada setiap tahapan. Berikut ini adalah hal-hal yang perlu dilakukan: (1) pada pendekatan objek lepasan (OP), umpan balik dapat berasal dari sesama guru / dosen yang me-reuse / me-repurpose objek lepasan (OP); (2) mengevaluasi pelaksanaan dan hasil dari setiap tahapan; (3) mengevaluasi objek lepasan (OP); (4) mengevaluasi metadata; (5) menentukan dampak dari pengalaman belajar kepada pembelajar; dan (6) menganalisis kepuasan pembelajar, hasil belajar, dan kelulusan. Tahap pemeliharaan bertujuan agar produk dapat digunakan berkelanjutan. Pengembangan materi e-Pembelajaran berorientasi objek pembelajaran memungkinkan kontribusi dari semua pemangku kepentingan untuk mengakses repositori, menambahkan, menggunakan kembali dan merangkai objek pembelajaran dengan mudah sehingga pemeliharaan materi e-Pembelajaran menjadi lebih mudah dan lebih efisien. Meskipun tahap ini tidak nampak pada model pengembangan yang lain, namun sebenarnya tahapan ini sudah umum dilakukan, yakni: (1) menjaga e-Materi selalu relevan; (2) menjaga e-Materi selalu up-to-date; (3) meng-update metadata e-Materi; dan (4) memanfaatkan hasil evaluasi untuk perbaikan dan pemeliharaan e-Materi.

\section{Animasi Courselab}

CourseLab merupakan piranti lunak penyusun bahan ajar multimedia untuk e-Learning yang powerful dan mudah digunakan. CourseLab menawarkan lingkungan WYSIWYG (What You See Is What You Get) yang bebas dari pemrograman untuk menghasilkan bahan ajar interaktif yang dapat dipublikasikan di internet, Learning Management Systems (LMS), serta CD-ROM (compact disc atau Kaset CD). E-materi yang telah disajikan oleh guru merupakan rangkuman serangkaian materi yang akan dibahas oleh guru. E-materi ini disajikan dalam betuk elektronik yang memudahkan siswa untuk mengakses materi yang akan diajarkan, sehingga siswa lebih mudah dalam mempelajari materi yang akan dibahas atau dipelajari. Dalam cakupan materi, E-materi ini lebih sempit dibandingkan dengan bahan ajar yang telah disediakan pada umumnya. Sehingga siswa lebih mudah dalam memahami materi yang akan dibahas oleh guru. Courselab ini merupakan alternatif yang dapat digunakan guru untuk pembelajaran kepada siswa khususnya Kelas V. Hal yang pada umumnya siswa Kelas V senang dengan hal baru yang sebelumnya mereka belum tahu. Courselab ini membuat pelajaran lebih menjadi variatif dan menyenangkan, sehingga menumbuhkan minat anak untuk mengikuti pembelajaran.

\section{Pembelajaran Ilmu Pengetahuan Sosial}

IPS sebagai progam pendidikan, tidak hanya menyajikan pengetahuan sosial semata, melainkan harus pula membina peserta didik menjadi warga masyarakat dan warga negara yang memiliki tanggung jawab atas kesejahteraan bersama dalam arti yang seluas-luasnya (Sumaatmaja, 2008: 17). Menurut Sapriya (2009: 6) matapelajaran IPS merupakan sebuah nama matapelajaran integrasi dari matapelajaran Sejarah, Geografi, dan Ekonomi serta matapelajaran ilmu sosial lainnya. Ciri khas IPS sebagai matapelajaran pada jenjang pendidikan dasar dan menengah adalah sifat terpadu (integrated) dari sejumlah matapelajaran ini lebih 
bermakna bagi peserta didik sehingga pengorganisasian materi / bahan pelajaran disesuaikan dengan lingkungan, karakteristik, dan kebutuhan peserta didik. Oleh karena itu, dalam perkembangannya muncul berbagai pendekatan yang berorientasi pada kebutuhan peserta didik.

IPS di tingkat sekolah pada dasarnya bertujuan untuk mempersiapkan para peserta didik sebagai warga negara yang menguasai pengetahuan (knowledge), keterampilan (skills), sikap dan nilai (attitudes and values) yang dapat digunakan sebagai kemampuan untuk memecahkan masalah pribadi atau masalah sosial serta kemampuan mengambil keputusan dan berpartisiasi dalam berbagai kegiatan kemasyarakatan agar menjadi warga negara yang baik. Trianto (2010: 171) berpendapat IPS dirumuskan atas dasar realitas dan fenomena sosial yang diwujudkan satu pendekatan interdisipliner dari aspek dan cabang-cabang ilmuilmu sosial (sosiologi, sejarah, geografi, ekonomi, politik, hukum, dan budaya). Sedangkan Sumantri mendefinisikan pendidikan IPS dalam dua jenis, yakni pendidikan IPS untuk persekolahan dan pedidikan IPS untuk perguruan tinggi (Sapriya, 2009: 11). Pendidikan IPS adalah penyederhanaan atau adaptasi dari disiplin ilmu-ilmu sosial dan humaniora, serta kegiatan dasar manusia yang diorganisasikan dan disajikan secara ilmiah dan psikologis untuk tujuan pendidikan. Pendidikan IPS adalah seleksi atau adaptasi dari disiplin ilmu-ilmu sosial dan humaniora, serta kegiatan dasar manusia yang diorganisasikan dan disajikan secara ilmiah dan psikologis untuk tujuan pendidikan.

Lebih lanjut Sumantri mengartikan pendidikan IPS yang diajarkan sekolah yakni: (1) pendidikan IPS yang menekankan pada tumbuhnya nilai-nilai kewarganegaraan; (2) pendidikan IPS yang menekankan pada isi dan metode berpikir keilmuan sosial; dan (3) pendidikan IPS yang menekankan pada reflective in quiry (Nurdin, 2005: 23). Berdasarkan penjelasan tersebut, dapat disimpulkan bahwa IPS adalah matapelajaran yang terintegrasi dari beberapa matapelajaran ilmu sosial yang dirumuskan atas dasar realitas dan fenomena sosial yang diorganisasikan dan disajikan secara ilmiah dan psikologis untuk tujuan pendidikan. Hasan menyebutkan bahwa IPS bertujuan untuk mengembangkan kemampuan berpikir, sikap, dan nilai peserta didik sebagai individu maupun sebagai sosial budaya (Nurdin, 2005: 24). Sedangkan Fajar (2002: 110-111) berpendapat fungsi dan tujuan matapelajaran IPS di SD dan MI. Fungsi matapelajaran IPS di SD dan MI adalah untuk mengembangkan pengetahuan, nilai, sikap, dan keterampilan siswa tentang masyarakat, bangsa, dan negara Indonesia. Tujuan matapelajaran IPS di SD dan MI adalah: (1) mengajarkan konsep-konsep dasar sosiologi, geografi, ekonomi, sejarah, dan kewarganegaraan melalui pendekatan pedagogis dan psikologis; (2) mengembangkan kemampuan berpikir kritis dan kreatif, inkuiri, memecahkan masalah, dan keterampilan sosial; (3) membangun komitmen dan kesadaran terhadap nilai-nilai sosial dan kemanusiaan; dan (4) meningkatkan kemampuan bekerjasama dan berkompetisi dalam masyarakat yang majemuk, baik secara nasional maupun global.

Lebih lanjut Fajar (2002: 111) merumuskan ruang lingkup matapelajaran Ilmu Sosial, yaitu: (1) sistem sosial dan budaya; (2) manusia, tempat, dan lingkungan; (3) perilaku ekonomi dan kesejahteraan; (4) waktu, keberlanjutan, dan perubahan; dan (5) sistem berbangsa dan bernegara. Dalam penelitian ini materi yang digunakan ialah materi IPS Kelas IV Semester II Bab 7 tentang menghargai jasa dan peranan tokoh perjuangan dalam mempersiapkan 
kemerdekaan Indonesia. Adapun penjabarannya: (1) standar kompetensi, menghargai peranan tokoh pejuang dan masyarakat dalam mempersiapkan dan mempertahankaan kemerdekaan Indonesia; dan (2) kompetensi dasar, menghargai jasa dan peranan tokoh perjuangan dalam mempersiapkan kemerdekaan Indonesia. Strategi pembelajaran IPS, adalah:

a. Strategi urutan penyampaian suksesif, jika guru harus menyampaikan materi pembelajaran lebih daripada satu, maka menurut strategi urutan suksesif, sebuah materi satu demi satu disajikan secara mendalam pula;

b. Strategi penyampaian fakta, jika guru harus menyajikan materi pembelajaran termasuk jenis fakta (nama-nama benda, nama tempat, peristiwa sejarah, nama orang, dan nama lambang atau simbol) strategi yang tepat untuk mengajarkan materi tersebut dalah sebagai berikut. Pertama, sajikan materi fakta degan lisan, tulisan atau gambar. Kemudian berikan bantuan kepada siswa untuk menghafal. Bantuan diberikan secara bermakna, menggunakan jembatan ingatan, jembatan keledai, dan asosiasi berpasangan;

c. Strategi penyampaian konsep. Materi pembalajaran jenis konsep adalah materi berupa definisi atau pengertian. Tujuan mempelajari konsep adalah agar siswa paham, dapat menunjukan ciri-ciri, unsur, membedakan, membandingkan, dan menggeneralisasi. Langkah-langkah mengajarkan konsep: (1) menyajikan konsep; (2) pemberian bantuan (berupa intisari, ciriciri pokok, contoh dan buat contoh); (3) pemberian latihan (exercise) misalnya berupa tugasuntuk mencari contoh lain; (4) pemberian umpan balik; dan (5) pemberian tes;

d. Strategi penyampaian materi pembelajaran prinsip, yang termasuk materi pembelajaran jenis prinsip atau dalil, rumus, hukum, postulat, dan teori. Langkah-langkah untuk mengajarkan atau menyampaikan materi pembelajaran jenis prinsip adalah: (1) sajikan prinsip oleh siswa hasil penelusuran perpustakaan lewat penugasan; (2) berikan bantuan berupa contoh penerapan prinsip dalam kehidupan sehari-hari; (3) berikan soal-soal latihan; (4) berikan umpan balik; dan (5) berikan tes atau penilaian praktik;

e. Strategi penyampaian prosedur. Tujuan mempelajari prosedur adalah agar siswa dapat melakukan atau mempraktikan prosedur tersebut, bukan sekedar paham atau hafal. Termasuk materi pembelajaran jenis prosedur adalah langkah-langkah mengerjakan suatu tugas secara urut. Langkah-langkah mengajarkan prosedur, ialah: (1) menyajikan prosedur; (2) pemberian bantuan dengan jalan mendemonstrasikan bagaimana melaksanakan prosedur; (3) memberikan latihan atau praktik; (4) memberikan umpan balik; dan (5) memberikan tes;

f. Strategi menyamaikan materi aspek sikap. Termasuk materi pembelajaran aspek sikap (afektif) adalah pemberian respons, penerimaan suatu nilai, internalisasi, dan penilaian. Beberapa strategi mengajarkan materi aspek sikap: penciptaan kondisi, pemodelan atau contoh, demonstrasi, simulasi.

Materi yang akan dibahas ialah: para tokoh dan pemimpin bangsa Indonesia di dalam mempersiapkan kemedekaan Indonesia. Guna mencapai Kemerdekaan Indonesia rakyat telah mengadakan berbagai usaha. Usaha-usaha yang dilakukannya itu untuk menjadi panduan bilamana Indonesia telah merdeka. Ada beberapa kegiatan yang dilakukan oleh para pemimpin dan tokoh bangsa 
Indonesia dalam mempersiapkan kemerdekaan. Hal ini ditunjukan proklamasi kemerdekaan dapat dilaksanakan sesuai dengan waktu yang tepat. Di harapkan juga agar proklamasi kemerdekaan dapat di ketehui oleh seluruh masyarakat indonesia. Kenyataannya, justru proklamasi ini bukan hanya dapat diketahui rakyat Indonesia yang ada di wilayah Indonesia, tetapi menyebar ke luar negeri.

\section{METODE PENGEMBANGAN}

Metode penelitian yang digunakan adalah penelitian dan pengembangan (research and development). Metode penelitian dan pengembangan (research and development) adalah metode penelitian yang digunakan untuk menghasilkan produk tertentu, dan menguji keefektifan produk tersebut (Sugiyono, 2010: 407). Menurut Kemp pengembangan perangkat merupakan suatu lingkaran yang kontinu (Trianto, 2010: 81). Tiap-tiap langkah pengembangan berhubungan dengan aktivitas revisi. Pengembangan perangkat dapat dimulai dari titik mana pun di dalam siklus tersebut. Oleh karena itulah peneliti melakukan penelitian dengan metode R\&D untuk menghasilkan sebuah produk yang bermanfaat bagi dunia pendidikan sehingga proses pembelajaran menjadi lebih menarik dan inovatif.

Penelitian ini bermaksud untuk mengembangkan dan menghasilkan Emateri berbasis Courselab Kelas V SD yang diharapkan dapat mempermudah siswa dalam mempelajari materi dari pembelajaran yang dilakukan. Menurut Sudjana untuk melaksanakan pengembangan perangkat pembelajaran diperlukan model-model pengembangan yang sesuai dengan sistem pendidikan (Trianto, 2009: 177). Model merupakan seperangkat prosedur yang berurutan untuk mewujudkan suatu proses. Sehingga model pengembangan E- materi merupakan seperangkat prosedur yang berurutan untuk mengembangkan E-Materi berbasis Courselab. Pada penelitian ini, pengembangan E-materi berbasis Courselab dilakukan mengikuti langkah pengembangan 4-D yang dikemukakan oleh Thiagarajan (Trianto 2010: 93). Model ini terdiri dari 4 tahap pengembangan, yaitu define, design, develop, and desseminate atau diadaptasi menjadi model 4-P, yaitu pendefisinisian, perancangan, pengembangan, dan penyebaran.

\section{Tahap Pendefinisian (Define)}

Tujuannya adalah menetapkan dan mendefinisikan syarat-syarat pembelajaran. Terdapat 5 langkah pokok dalam tahap ini yaitu:

a. Analisis ujung depan. Hal-hal yang dilakukan pada langkah ini adalah: (1) mempertimbangkan apakah kurikulum yang berlaku bisa mencapai tujuan yang diinginkan. Untuk mengetahuinya kegiatan yang dilakukan yaitu menghimpun informasi tentang permasalahan yang terjadi terhadap pelaksanaan pendidikan pada umumnya; dan (2) mempertimbangkan kesenjangan keadaan awal siswa dengan apa yang seharusnya akan dicapai siswa. Untuk mengetahuinya perlu diadakan telaah kebutuhan materi yang dapat menutup kesenjangan tersebut;

b. Analisis siswa. Kegiatan yang dilakukan pada langkah ini adalah: (1) membentuk kelompok secara heterogen; (2) penyesuaian diri terhadap sesama anggota kelompok dan memastikan kemampuan bekerjasama baik, karena karakteristik berbeda; 
c. Analisis tugas. Kegiatan yang dilakukan pada langkah ini adalah: (2) siswa memulai mengerjakan buku; (2) memahami maksud dari pertanyaan yang akan dikerjakan; (3) menyelesaikan soal pemecahan masalah; dan (4) menyerahkan hasil dari penyelesaian soal;

d. Analisis konsep. Kegiatan yang dilakukan pada langkah ini adalah: (1) menemukan konsep atau landasan teoristis yang memperkuat pengembangan E-materi berbasis Courselab; dan (2) menyusun secara sistematis dan merinci konsep yang relevan dan memperkuat pengembangan E-materi berbasis Courselab;

e. Perumusan tujuan. Kegiatan yang dilakukan pada langkah ini adalah: (1) menentukan tujuan dari pembuatan E-materi yang berbasis Courselab; dan (2) menyusun produk yaitu E-materi yang berbasis Courselab.

\section{Tahap Perancangan (Design)}

Adapun format rancangan pengembangan E- Materi berbasis Courselab Kelas V yang akan dikembangkan adalah:

a. Bagian prapendahuluan

1) Halaman sampul

2) Pengantar bagi pengguna E-materi

3) Petunjuk guru / siswa

b. Bagian Pendahuluan

1) Standar Kompetensi (SK) dan Kompetensi Dasar (KD)

2) Uraian pendahuluan materi

3) Petunjuk pengantar

c. Bagian Inti

1) Rangkuman materi

2) Pengayaan

3) Latihan soal siswa

d. Glosarium

e. Daftar Pustaka

\section{Tahap Pengembangan (Develop)} dihasilkan:

Berdasarkan kegiatan pendefinisian dan perancangan pada tahap ini

a. Validasi E-materi berbasis Courselab oleh ahli

E-materi dan instrumen penelitian yang telah dikembangkan pada tahap ini akan diuji kelayakannya oleh ahli. Uji kelayakan dilakukan dengan meminta penilaian kepada validator ahli yaitu: dosen, kepala sekolah, dan guru.

b. Simulasi

E-materi yang dikembangkan adalah E-materi berbasis Courselab. Emateri ini digunakan siswa untuk mempermudah siswa dalam menguasai konsepkonsep pelajaran dan membantu guru dalam penyampaian materi agar siswa lebih mudah dalam pemahaman materi yang telah disampaikan. Pada langkah ini kegiatan yang dilakukan adalah mengoperasionalkan E-materi yang dikembangkan.

c. Uji coba terbatas

Uji coba ini dilakukan pada siswa yang sesungguhnya namun hanya terbatas pada beberapa siswa saja. Hasil dari simulasi dan uji coba terbatas 
digunakan sebagai dasar revisi. Langkah berikutnya adalah uji coba lebih lanjut dengan jumlah siswa yang sesuai dengan kelas sesungguhnya.

\section{Tahap Penyebaran (Dessiminate)}

Tahap ini merupakan tahapan penggunaan perangkat yang telah dikembangkan pada skala yang lebih luas misalnya di kelas lain atau di sekolah lain oleh guru yang lain. Tujuan pada tahap ini juga untuk menguji efektivitas penggunaan perangkat di dalam pembelajaran.

Langkah-langkah pengembangan diilustrasikan pada Gambar 1. Berdasarkan Gambar 1 diuraikan penjelasan tiap-tiap tahap pengembangan Emateri berbasis Courselab untuk siswa Kelas V sekolah dasar ialah:

\section{Penentuan Tujuan}

Pada tahap ini yang harus dilakukan oleh peneliti adalah menentukan tujuan yang ingin dicapai dari pengembangan E-materi berbasis Courselab. Tujuan yang hendak dicapai oleh peneliti adalah menghasilkan sebuah produk berupa E-materi berbasis Courselab yang diharapkan dapat mempermudah siswa dalam memahami konsep-konsep materi yang akan diajarkan dengan pembelajaran yang menarik dan menyenangkan, sehingga memotivasi siswa untuk lebih giat belajar serta pembelajaran menjadi lebih bermakna.

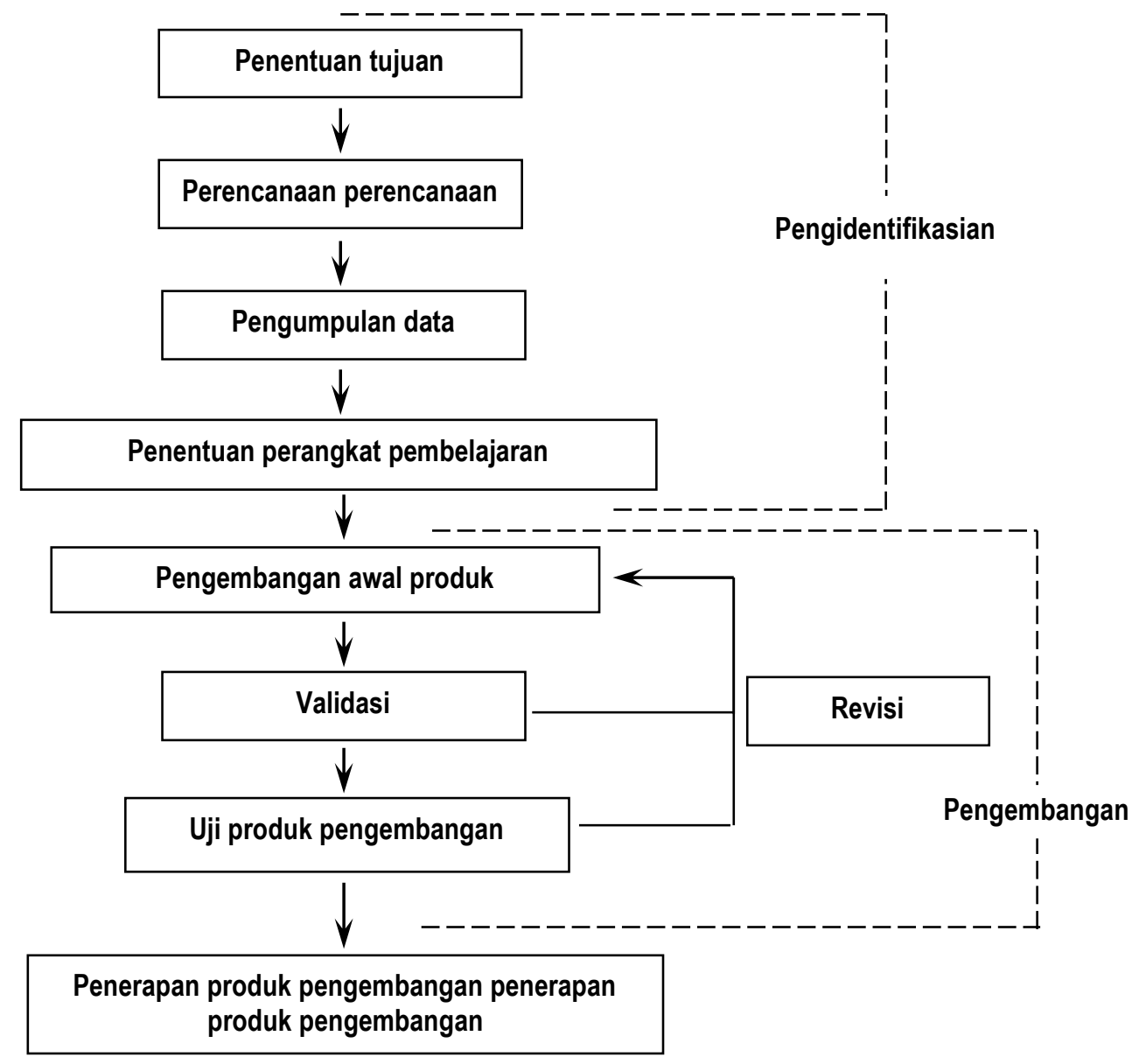

Gambar 1 Model Pengembangan E-materi Berbasis Courselab 


\section{Perencanaan}

Kegiatan yang dilakukan pada tahap ini adalah merencanakan dan merancang format dari produk yang akan dikembangkan yang berupa E-materi berbasis Courselab. Adapun format dari E-materi yang dikembangkan adalah:

a. Bagian prapendahuluan

1) Halaman sampul

2) Pengantar bagi pengguna E-materi

3) Petunjuk guru / siswa

b. Bagian Pendahuluan

1) Standar Kompetensi (SK) dan Kompetensi Dasar (KD)

2) Uraian pendahuluan materi

3) Petunjuk pengantar

c. Bagian Inti

1) Gambar-gambar yang berkaitan dengan materi

2) Kegiatan Latihan Siswa

3) Rangkuman Materi

4) Pengayaan

d. Glosarium

e. Daftar Pustaka

\section{Pengumpulan Data}

Masalah yang dihadapi di sini adalah belum tersedianya materi yang hanya membahas pada pokok bahasan yang akan diajarkan oleh guru, materi yang ada terlalu luas untuk dipelajari untuk Kelas V SD. Guru masih belum bisa mengoptimalkan materi pembelajaran karena pada umumnya materi IPS untuk Kelas V SD masih terlalu luas untuk dipelajari. Masalah yang paling penting adalah bahan ajar yang tersedia masih berupa fakta dan sesuatu yang harus dipahami oleh siswa sehingga pembelajaran terasa kurang bermakna.

Solusi yang dapat diambil salah satunya adalah dengan dilakukannya pengembangan E-materi berbasis Courselab yang didesain untuk membangun motivasi belajar siswa sehingga proses pembelajaran menjadi lebih bermakna dan menyenangkan. Pengumpulan data untuk mengembangkan E-materi berbasis Courselab tersebut meliputi: (1) melakukan observasi untuk mengumpulkan data awal mengenai potensi dan masalah yang ada di Kelas V SDN Tapak Panekan Magetan; (2) mencari sumber pustaka, baik berupa buku maupun artikel dari internet dan literatur lainnya yang berkaitan dengan materi atau tema yang ditentukan; (3) angket; (4) deskripsi keterlaksanaan uji coba produk; dan (5) dokumentasi. Data yang diperoleh digunakan sebagai acuan dalam mengembangkan produk berupa E-materi berbasis Courselab.

\section{Penentuan Perangkat}

Pada tahap ini menentukan perangkat yang akan dikembangkannya. Berdasarkan tujuan di atas maka perangkat yang akan dikembangkan oleh peneliti adalah pengembangan E-materi berbasis Courselab. Pengembangan E-materi ini sebelumnya belum pernah dilakukan sehingga diharapkan nantinya produk yang dihasilkan dapat meningkatkan motivasi siswa untuk belajar dan pembelajaran menjadi lebih bermakna. 


\section{Pengembangan Awal}

Pada tahap ini peneliti mulai mengembangkan perangkat pembelajaran Emateri berbasis Courselab. Peneliti mengembangkan E-materi sesuai dengan format yang telah dibuat pada tahap perencanaan.

\section{Validasi}

Validasi E-materi merupakan proses kegiatan untuk menilai apakah rancangan E-materi yang dikembangkan layak atau tidak untuk digunakan. Validasi produk dilakukan oleh beberapa pakar sudah berpengalaman dan berkompeten dalam hal ini untuk menilai E-materi baru yang telah dirancang. Pakar validasi E-materi selanjutnya disebut sebagai validator, terdiri dari 2 orang dosen pembimbing, 1 orang dosen independen atau pakar IT, 1 orang guru, dan 1 orang kepala sekolah.

Setiap pakar menilai desain buku tematik tersebut sehingga dapat diketahui kelebihan dan kekurangan buku yang dibuat. Validasi ini diukur menggunakan angket validasi dosen dan guru. Validasi E-materi yang dilakukan adalah validasi isi E-materi dan validasi proses ketika uji coba poduk. Validasi produk dilakukan dengan memberikan E-materi berbasis Courselab pada satu siswa dan guru serta 1 bendel angket kepada masing-masing validator. Selanjutnya para validator mengisi angket tersebut untuk memberikan penilaian terhadap produk yang telah dikembangkan. Para validator juga bisa memberikan saran / komentar terhadap produk tersebut dengan mengisikan pada kolom saran / komentar di bagian akhir angket. Selanjutnya saran / komentar dari validator akan dijadikan tambahan untuk revisi produk. Revisi produk yang paling utama adalah terletak pada hasil validasi angket.

\section{Revisi 1}

Setelah dilakukan validasi E-materi oleh para validator maka akan diketahui kelemahan-kelemahan dari E-materi yang dikembangkan. Selanjutnya, kelemahan tersebut diminimalisir dengan cara memperbaiki desain E-materi yang dilakukan oleh peneliti.

\section{Uji Produk Pengembangan}

Uji coba ini dilakukan pada siswa yang sesungguhnya yaitu siswa kelas V SDN Tapak Panekan Magetan namun hanya terbatas pada beberapa siswa saja. Uji coba ini selain untuk menguji produk yang dihasilkan juga digunakan sebagai instrumen untuk melihat prestasi belajar siswa setelah menggunakan E-matei berbasis Courselab.

\section{Revisi 2}

Revisi ini dilakukan apabila dalam uji coba E-materi masih terdapat kekurangan sehingga perlu dilakukan revisi oleh peneliti terhadap E-materi yang dikembangkan berdasarkan masukan dosen pembimbing. Apabila sudah direvisi dan sudah disetujui oleh dosen pembimbing maka produk yang berupa E-materi berbasis Courselab pada matapelajaran IPS telah layak untuk digunakan pada siswa Kelas V SDN Tapak Panekan Magetan. 


\section{Penerapan Produk}

Produk berupa E-matei berbasis Courselab yang sudah layak tadi kemudian diberikan kepada siswa Kelas V SDN Tapak Panekan Magetan untuk digunakan sebagai media dan sumber belajar yang inovatif, menarik, dan menyenangkan.

Uji coba E-materi dilakukan dengan memberikan E-materi yang telah direvisi pada siswa Kelas V SDN Tapak Panekan Magetan dengan jumlah 8 siswa. Pelaksanaan uji coba dilakukan dengan memberikan E-materi berbasis Courselab pada 2 orang siswa. Alokasi waktu yang dibutuhkan untuk uji coba Emateri ini adalah 4 X 35 menit yang akan dibagi dalam 2 pertemuan. Setelah kegiatan pembelajaran selesai, guru diminta mengisi angket opini berdasarkan respons siswa. Pada saat pelaksanaan uji coba E-materi, guru berperan membimbing siswa dan mencatat keterlaksanaan uji coba E-materi tersebut, kepala sekolah dan peneliti juga ikut memantau keterlaksanaan uji coba tersebut dan mengisi lembar deskripsi keterlaksanaan uji coba dan angket observasi kegiatan pembelajaran menggunakan E-materi.

\section{Subjek Uji Coba}

Subjek uji coba pertama adalah validator ahli yang terdi dari 2 orang dosen pembimbing, 1 orang dosen independen / pakar IT IKIP PGRI MADIUN, 1 orang kepala sekolah, 1 orang guru Kelas V Sekolah Dasar. Validator dalam pengembangan E-materi bebasis Courselab seperti pada Tabel 1.

Tabel 1 Validator Penelitian

\begin{tabular}{ccl}
\hline No & Validator & \multicolumn{1}{c}{ Keterangan } \\
\hline 1. & Validator 1 & Kaprodi PGSD IKIP PGRI Madiun \\
2. & Validator 2 & Dosen prodi PGSD IKIP PGRI Madiun \\
3. & Validator 3 & Dosen Pakar IT Prodi PGSD IKIP PGRI Madiun \\
4. & Validator 4 & Kepala Sekolah SDN Tapak Panekan Magetan \\
5. & Validator 5 & Guru Kelas V SDN Tapak Panekan Magetan \\
\hline
\end{tabular}

Subjek uji coba kedua adalah pengguna produk, yaitu siswa kelas V SDN Tapak Panekan Magetan sebanyak 22 siswa.

\section{Jenis Data}

Data yang diperoleh dari E-materi ini berupa data kuantitatif dan kualitatif. Dat kuantitatif berupa skor angket dari validator, observer, dan opini guru. Sedangkan data kualitatif berupa kesimpulan nilai kelayakan buku serta tanggapan dan saran yang diberikan oleh validator dan deskripsi keterlakasaan uji coba E-materi dari observer dan guru kelas.

\section{Instrumen Pengumpulan Data}

Instrumen pengumpulan data yang digunakan dalam pengembangan Emateri ini yaitu angket produk berupa E-materi dan lembar deskripsi keterlaksanaan uji coba E-materi. Angket yang digunakan terdiri dari 2 jenis, yaitu (1) angket validasi dan penilaian E-materi; dan (2) angket opini dari guru dan observer terhadap E-materi. Setiap angket memuat komentar / saran terhadap E-materi yang telah peneliti kembangkan. 


\section{Teknik Analisis Data}

Teknik analisis data yang digunakan dalam menganalisis data kuantitatif dengan penskoran angket dari kelayakan dan kevalidan E-materi yang didapat dari para validator. Selain itu, dapat juga dilakukan dengan membandingkan keadaan sebelum dan sesudah memakai E-materi berbasis Courselab (Sugiyono, 2011).

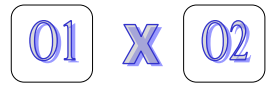

Keterangan:

O1 : Nilai sebelum treatmen

$\mathrm{O} 2$ : Nilai sesudah treatmen

\section{Gambar 2 Desain Ekperimen (Before-After)}

Berdasarkan Gambar 2, eksperimen dilakukan dengan membandingkan hasil observasi $\mathrm{O} 1$ dan $\mathrm{O} 2$. $\mathrm{O} 1$ merupakan nilai sebelum menggunakan E-materi bebasis Courselab; sedangkan $\mathrm{O} 2$ merupakan nilai setelah menggunakan E-materi berbasis Courselab. Penggunaan E-materi bebasis Courselab akan efektif apabila nilai $\mathrm{O} 2$ lebih besar dari O1. Untuk membuktikan signifikasi perbedaan prestasi sebelum dan sesudah menggunakan E-materi berbasis Courselab perlu diuji secara statistik dengan t-test. Rumus yang digunakan adalah:

$\mathrm{t}=\frac{\bar{X} 1-\bar{X} 2}{\sqrt{\frac{s_{1}^{2}}{n 1}+\frac{s_{2}^{2}}{n 2}-2 r\left(\frac{S 1}{\sqrt{n 1}}\right)\left(\frac{S 2}{\sqrt{n 2}}\right)}}$

Keterangan:

$\bar{X} 1$ : Rata-rata nilai sebelum menggunakan E-materi berbasis Courselab;

$\bar{X} 2$ : Rata-rata nilai setelah menggunakan E-materi berbasis Courselab;

s1 : Simpangan baku sebelum menggunakan E-materi berbasis Courselab;

s2 : simpangan baku sesudah menggunakan E-materi berbasis Courselab;

S1 : Varians sebelum menggunakan E-materi berbasis Courselab;

S2 : Varians sesudah menggunakan E-materi berbasis Courselab;

r : Korelasi antara data dua kelompok (Sugiyono, 2011: 307).

\section{HASIL PENELITIAN}

\section{Hasil Penelitian Pendahuluan}

Pada tahap awal penelitian dan pengembangan ini adalah menetapkan matapelajaran yang dikembangkan. Tahap selanjutnya adalah melakukan penelitian pendahuluan. Penelitian ini bertujuan untuk memperoleh data kebutuhan apa yang diperlukan oleh matapelajaran IPS, selain itu penelitian ini juga bertujuan untuk memperoleh data bagaimana konsep media yang akan dibuat. Penelitian pendahuluan dilakukan di SDN Tapak Panekan Magetan dengan metode observasi dan wawancara terhadap guru matapelajaran IPS.

Berdasarkan hasil observasi kelas dan wawancara dengan guru matapelajaran IPS di SDN Tapak Panekan Magetan, diperoleh beberapa konsep media pembelajaran. Media yang digunakan harus dapat menampilkan tulisan, 
gambar, video, dan animasi gerakan. Ada beberapa alternatif media pembelajaran yang akan digunakan, seperti: Courselab dan Macromedia Flash. Berdasarkan hasil penelitian pendahuluan ini, dihasilkan konsep media pembelajaran pada matapelajaran IPS SDN Tapak Panekan Magetan. Dari hasil konsep tersebut kemudian dibuat media yang sesuai dengan kebutuhan serta mudah dalam proses pembuatan dan penggunaannya yaitu dengan menggunakan software Courselab. Setelah media tersebut selesai dibuat kemudian divalidasi oleh ahli materi dosen dan guru matapelajaran IPS serta ahli dari dosen media pembelajaran.

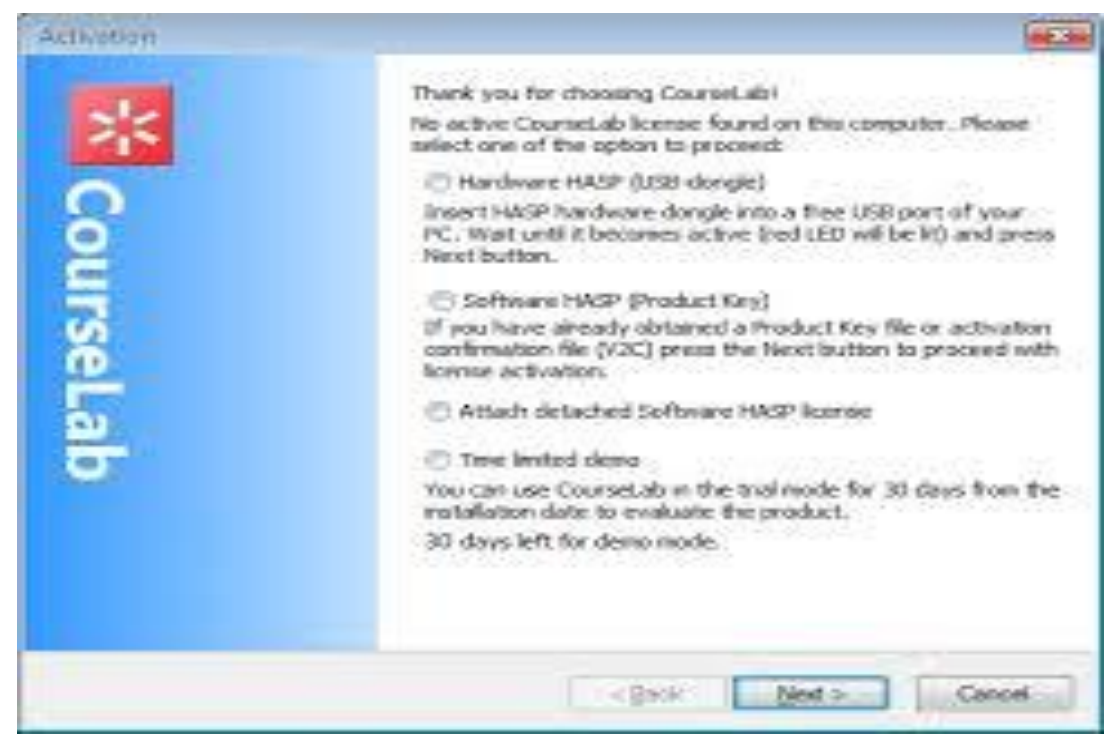

\section{Gambar 3 Tampilan CourseLab}

\section{Hasil Perancangan Materi Media Membelajaran}

Perancangan materi untuk media pembelajaran berbasis komputer pada matapelajaran IPS pokok bahasan menghargai jasa dan peranan tokoh perjuangan dalam mempersiapkan kemerdekaan Indonesia melaui beberapa tahap yaitu:

\section{a. Identifikasi Tujuan}

Pengembangan media pembelajaran berbasis komputer pada matapelajaran IPS bertujuan untuk mempermudah proses pembelajaran serta meningkatkan motivasi dan prestasi belajar siswa pada matapelajaran ini. Tujuan dari pembelajaran mengunakan media ini adalah agar siswa mampu untuk menguasai materi matapelajaran IPS baik secara teori dan praktik dalam penggunaan media Courselab. Di dalam matapelajaran IPS diajarkan keterampilan pengetahuan dan sikap agar kompeten dalam pengoperasian media Courselab. Struktur pembelajaran IPS pada kompetensi mengoperasikan media Courselab sesuai dengan silabus dan RPP yang telah dibuat.

\section{b. Analisis}

Tahap analisis dalam pembuatan materi matapelajaran IPS pokok bahasan menghargai jasa dan peranan tokoh perjuangan dalam mempersiapkan kemerdekaan Indonesia dilakukan dalam dua tahap, yaitu tahap analisis kebutuhan pengguna dan analisis instruksional. Tahap analisis kebutuhan untuk menelusuri permasalahan-permasalahan apa saja yang muncul dalam proses pembelajaran materi mengoperasikan media Courselab. Hasil identifikasi tahap analisis kebutuhan pemakaian, yaitu: (1) media pembelajaran harus memiliki tampilan 
yang menarik sehingga diharapkan dapat meningkatkan motivasi siswa; (2) media pembelajaran harus mudah digunakan oleh siapa saja yang ingin mempelajari materi; dan (3) media pembelajaran diharapkan dapat meningkatkan prestasi siswa di atas nilai ketuntasan. Media pembelajaran berbasis komputer belum banyak digunakan sebagai bahan ajar di sekolah. Dengan adanya media pembelajaran berbasis komputer diharapkan dapat menjadi solusi untuk meningkatkan motivasi dan prestasi belajar siswa. Media pembelajaran pada matapelajaran IPS berisi: gambar, teks, dan animasi, sehingga lebih mudah bagi peserta didik untuk menyerap materi pembelajaran yang diberikan dibandingkan dengan media konvensional.

Tahap analisis instruksional yaitu dengan melakukan penyesuaian antara materi yang ada pada silabus mata pelajaran IPS di SDN Tapak Panekan Magetan dengan materi mengoperasikan media Courselab yang disajikan dalam media pembelajaran. Materi yang disajikan pada media pembelajaran mengoperasikan media Courselab meliputi enam kompetensi dasar yaitu: memahami instruksi kerja, memasang fixtur perlengkapan alat pemegang, melakukan pemeriksaan awal, mengoperasikan mesin IPS/NC, pengawasan mesin, dan mengganti alat potong yang rusak atau retak.

\section{c. Review Instruksional}

Tahap review instruksional merupakan pengkajian ulang tentang pengembangan media pembelajaran yang digunakan. Pada tahap ini ditekankan pada aspek manfaat dan kesesuaian materi dengan tujuan yang ingin dicapai. Apakah pengembangan media pembelajaran benar-benar dapat menjadi solusi dari permasalahan-permasalahan yang ada di SDN Tapak Panekan Magetan? Apakah pengembangan media pembelajaran ini tepat-guna? Keadaan di sekolah, ada beberapa peserta didik yang belum memiliki motivasi untuk belajar dalam proses pembelajaran dan mereka belum berpikir untuk belajar secara serius. Penyampaian materi secara konvensional dengan metode ceramah membuat motivasi peserta didik menjadi rendah, karena materi yang disampaikan kadang membuat bingung, sebab penjelasan yang diberikan kurang dapat dicerna atau masih bersifat abstrak. Sehingga penggunaan media pembelajaran berbasis komputer diharapkan dapat menjadi solusi terhadap permasalahan tersebut yaitu dapat meningkatkan motivasi dan prestasi bealajar siswa.

\section{d. Merumuskan kompetensi dasar}

Kompetensi dasar dirumuskan dan disesuaikan dengan tujuan pembelajaran. Kompetensi dasar yang terdapat dalam silabus matapelajaran IPS pokok bahasan menghargai jasa dan peranan tokoh perjuangan dalam mempersiapkan kemerdekaan Indonesia adalah: (1) melaksanakan instruksi kerja; (2) melakukan pemeriksaan awal; (3) memasang fixtur perlengkapan alat pemegang; dan (4) mengoperasikan media pembelajaran.

\section{e. Mengembangkan kriteria}

Kriteria keberhasilan dikembangkan sesuai dengan kompetensi dasar yang ada sesuai dengan silabus matapelajaran IPS. Dimana kriteria tersebut merupakan bagian dari sub-sub kompetensi dasar, sehingga materi yang ada pada sub-sub kompetensi dasar dapat dikembangkan lebih dalam lagi.

\section{f. Membuat storyboard}

Storyboard merupakan pemikiran yang divisualisasikan dan dideskripsikan melalui tulisan E-materi, dan direncanakan dalam narasi. Hasil dari penulisan 
storyboard akan digunakan dalam proses produksi program multimedia, sehingga dalam proses produksi program multimedia akan lebih terstruktur dan teratur.

\section{Hasil Pengembangan Software Media Pembelajaran}

Hasil pengembangan Software media pembelajaran pada matapelajaran IPS pokok bahasan menghargai jasa dan peranan tokoh perjuangan dalam mempersiapkan kemerdekaan Indonesia berupa software, media pembelajaran yang dikemas dalam Compact Disc (CD). Beberapa tahapan yang dilakukan dalam pengembangan Software yaitu:

\section{a. Analisis}

Hasil analisis tahap perancangan media pembelajaran ini dibagi dalam dua tahap, yaitu tahap analisis spesifikasi teknis dan tahap analisis kerja program. Tahap analisis spesifikasi teknis untuk mengetahui persyaratan minimal sebuah personal computer (PC) untuk dapat menjalankan media pembelajaran berbasis komputer. Media pembelajaran berbasis komputer ini dapat bekerja dalam sistem operasi Windows XP, Windows Vista, dan Windows 7. Untuk dapat menampilkan dan mengoperasikan program pada layar monitor, dengan kualitas baik disarankan penggunaan prosessor dengan kecepatan di atas $1 \mathrm{GHz}$ dan memori $1 \mathrm{~GB}$. Software yang digunakan sebagai program utama dalam pembuatan media pembelajaran berbasis komputer ini yaitu dengan program Courselab, sedangkan program pendukung yaitu $p d f$ untuk teks, jetaudio untuk pengeditan video dan suara, office picture manager untuk pengeditan gambar, serta nero untuk dokumentasi ke dalam bentuk CD. Perangkat keras untuk menjalankan media pembelajaran berbasis komputer ini adalah sebuah unit komputer yang dilengkapi dengan $C D$ Room $R W$ untuk keperluan membaca dan burning media pembelajaran dalam format $\mathrm{CD}$, monitor SVGA atau LCD untuk menampilkan program, keyboard dan mouse standar windows untuk keperluan interaksi dengan program, serta speaker aktif untuk mengakses sounds yang ada dalam media pembelajaran.

Tahap analisis kerja program dilakukan untuk mengetahui kerja dari media pembelajaran berbasis komputer yang telah dibuat. Kerja media pembelajaran interaktif didesain untuk mempermudah pengguna untuk mempelajari matapelajaran IPS pokok bahasan menghargai jasa dan peranan tokoh perjuangan dalam mempersiapkan kemerdekaan Indonesia, dimana pengguna dapat berinteraksi memberi masukan melalui mouse atau keyboard untuk mendapatkan respons dari komputer berupa animasi, teks, gambar, narasi, dan video. Adapun hasil identifikasi dari tahap analisis kerja media pembelajaran mengoperasikan media courselab ini ialah:

1) Pada saat program dibuka dan dijalankan, maka akan ditampilkan halaman muka (cover), yang disertakan pada pojok kanan bawah tombol Start dan pada pojok kanan atas tombol close. Jika tombol ika tombol start dipilih akan masuk ke halaman pengantar program atau selamat datang. Jika tombol close dipilih akan keluar halaman program;

2) Pada halaman pengantar / selamat datang terdapat tombol prev-next dan close. Untuk melanjutkan program ke menu utama atau halaman kompetensi, pilih next;

3) Setelah masuk ke menu utama, terdapat tiga pilihan kompetensi dasar. Untuk menuju ke materi, pilih next; 
4) Dalam menu materi ini untuk mempermudah navigai juga disediakan tombol next-prev, first page-last page, home, pada pojok kanan bawah dan tombol close pada pojok kanan atas. Untuk memilih materi kompetensi dasar yang lain, pilih tombol home atau langsung di-klik pada kotak sub-sub kompetensi pada halaman atas;

5) Dalam tampilan materi masing-masing pokok bahasan maupun sub pokok bahasan, ada beberapa tampilan dijumpai adanya tombol movie. Tombol tersebut di-klik akan menampilkan video atau animasi sesuai dengan keterangan yang disampaikan dalam tombol tersebut. Untuk kembali ke materi dan menutup tampilan tersebut di-klik tombol next-prev yang terdapat pada pojok kanan bawah maupun kanan atas dari tampilan gambar atau video tersebut;

6) Setetelah program selesai digunakan, untuk menutupnya gunakan tombol close.

\section{b. Desain Program}

Setelah materi pembalajaran disusun maka proses yang selanjutnya dilakukan adalah desain program. Desain program adalah langkah pertama dalam fase pengembangan media pembelajaran berbasis komputer. Tahap-tahap desain media adalah:

1) Diagram Alir

Diagram alir program merupakan bagan dengan simbol-simbol tertentu yang menggambarkan urutan proses dan hubungan antara proses secara mendetail dalam suatu program. Diagram alir program digunakan untuk menggambarkan tiap-tiap langkah di dalam program komputer secara logika.

\section{2) Desain Interface}

Tahap desain interface adalah penggambaran mengenai struktur program. Desain interface atau tampilan dibuat untuk memudahkan dalam menterjemahkan ke dalam bentuk bahasa pemrograman. Desain interface dibuat berdasarkan flowchart yang telah dibuat pada tahap desain digram alir. Berikut ini adalah desain interface media pembelajaran berbasis komputer matapelajaran IPS pokok bahasan menghargai jasa dan peranan tokoh perjuangan dalam mempersiapkan kemerdekaan Indonesia:

\section{a) Desain Halaman Muka (Cover)}

Desain halaman muka dari media pembelajaran ini terdiri dari tulisan judul media pembelajaran terdapat pada bagian tengah halaman muka. Pada pojok bawah terdapat tombol profil untuk melihat data pembuat media, tombol Help untuk melihat petunjuk penggunaan media, tombol Start untuk masuk ke program media, dan pada pojok kanan atas terdapat tombol X untuk keluar dari program.

b) Desain Halaman Pengantar

Desain halaman pengantar pada media ini yaitu pada atasnya terdapat tulisan materi pembelajaran IPS. Terdapat pula untuk melanjutkan ke halaman berikutnya kembali ke halaman muka.

c) Desain Halaman Kompetensi

Desain halaman kompetensi ini terdiri dari judul halaman kompetensi pada baian paling atas, kemudian di bawak terdapat tombol untuk kompetensi dasar I, kemudian kanannya kompetensi dasar II, seterusnya sampai kompetensi dasar III. 
Pada bagian pojok kanan bawah terdapat navigasi untuk menuju halaman sebelumnya, halamnan berikutnya, halaman awal, halaman terakhir. Selain itu juga terdapat tombol navigasi yang terletak bagian pojok kanan atas untuk keluar dari program.

d) Desain Halaman Materi

Desain halaman materi ini pada bagian atasnya terdapat halaman pilihan kompetensi dasar. Kemudian pada sebelah kiri terdapat sub-sub tombol kompetensi dan pada bagian bawahnya terdapat enam sub-sub materi tersusun dari atas ke bawah dan tombol-tombol: navigasi next, prev, home, dan close.

\section{c. Implementasi Program}

Implementasi program adalah tahap menterjemahkan atau memindah desain E-matei ke tampilan sebenarnya dalam bentuk Courselab. Implementasi program media pembelajaran berbasis komputer pada mata pelajaran IPS pokok bahasan menghargai jasa dan peranan tokoh perjuangan dalam mempersiapkan kemerdekaan Indonesia adalah: (1) implementasi halaman muka (cover); (2) implementasi halaman kompetensi (home); dan (3) implementasi halaman materi.

\section{d. Teknik Pengujian Program}

Teknik pengujian kerja program media pembelajaran pada matapelajaran IPS pokok bahasan menghargai jasa dan peranan tokoh perjuangan dalam mempersiapkan kemerdekaan Indonesia, dilakukan dengan menjalankan program dari awal sampai akhir, kemudian mencoba setiap menu, submenu dan tomboltombol navigasi yang telah di-hyperlink. Tahap pertama pengujian adalah membuka file dan menjalankan media pembelajaran berbasis komputer. Setelah file dibuka akan muncul halaman cover, halaman profil, halaman petunjuk, halaman kompetensi. dan halaman kompetensi dasar I s.d. III. Pengujian kerja media pembelajaran yang pertama dimulai dari halaman cover, yaitu: (1) pengujian tombol profil; (2) pengujian tombol help (petunjuk); (3) pengujian tombol suara; (4) pengujian tombol close; (5) dan pengujian tombol start.

Pengujian yang kedua adalah halaman selamat datang yaitu dilakukan dengan mengecek: (1) tombol next; dan (2) tombol prev. Pengujian yang ketiga adalah halaman kompetensi yaitu dilakukan dengan mengecek: (1) tombol next; dan (2) tombol prev. Pengujian keempat adalah halaman kompetensi yaitu dilakukan dengan: (1) mencoba tombol-tombol kompetensi dasar; dan (2) mencoba tombol navigasi yaitu tombol next-prev, first-page, last-page, dan close. Pengujian yang kelima adalah halaman kompetensi yaitu dilakukan dengan: (1) mencoba tiap bagian dari kompetensi dasar I s.d. VI; (2) mengecek tombol materi dalam setiam kompetensi dasar I s.d. VI; (3) mengecek link rumus pada Microsoft Excel; (4) mengecek gerakan animasi; (5) mengecek video dan gambar; (6) mengecek tombol navigasi yaitu tombol next-prev, first page-last page, dan close, pada setip halaman kompetensi. Pengujian program dilakukan dari pada setiap halaman media yang telah dibuat dimulai dari halaman cover, halaman selamat datang, halaman kompetensi, sampai dengan halaman kompetensi dasar I s.d. III. Setelah pengujian selesai dilakukan kemudian dilakukan perbaikan dan selanjutnya dilakukan validasi media pembelajaran pada ahli materi dan ahli media pembelajaran. 


\section{Hasil Pengujian}

Tahap pengujian media pembelajaran berbasis komputer dilakukan sesuai dengan rancangan pengembangan media berbasis komputer yang digunakan (Gambar 1). Pengujian dilakukan dengan melakukan validasi media yang terdiri dari ahli media pembelajaran, ahli materi dari dosen dan guru matapelajaran. Data dan saran yang ada pada instrumen digunakan sebagai bahan pertimbangan untuk perbaikan dan merevisi media pembelajaran. Hasil validasi dari ahli media pembelajaran, ahli materi dari dosen dan guru mata pelajaran adalah:

\section{a. Hasil Penilaian Ahli Media Pembelajaran}

Aspek penilaian untuk ahli media pembelajaran ditinjau dari aspek:(1) halaman sampul; (2) tabel; dan (3) gambar. Hasil validasi dan penilaian ahli media pembelajaran oleh dosen ahli media pembelajaran disajikan pada Tabel 2 .

Tabel 2 Penilaian Dosen Ahli Media Pembelajaran

\begin{tabular}{clccc}
\hline No & Aspek Penilaian & Skor Observasi & $\begin{array}{c}\text { Skor yang } \\
\text { Diharapkan }\end{array}$ & Kelayakan \\
\hline 1 & Halaman sampul & 113 & 120 & $94,17 \%$ \\
2 & Tabel & 37 & 40 & $92,50 \%$ \\
3 & Gambar & 39 & 40 & $97,50 \%$ \\
\hline & Jumlah & $\mathbf{1 8 9}$ & $\mathbf{2 0 0}$ & $\mathbf{9 4 , 5 0 \%}$ \\
\hline
\end{tabular}

Berdasarkan Tabel 2 diketahui rata-rata total penilaian dari tentang media pembelajaran berbasi komputer dengan sebesar 94,50\%. Sesuai dengan skala persentase, hasil tersebut dalam kategori layak untuk digunakan.

\section{b. Hasil Penilaian Ahli Materi}

Ahli materi pembelajaran ditinjau dari: (1) kompetensi dasar; (2) tujuan pembelajaran; (3) uraian pendahuluan kegiatan belajar siswa; dan (4) kegiatan belajar siswa. Hasil validasi dari dosen ahli materi seperti disajikan pada Tabel 3.

\section{Tabel 3 Penilaian Dosen Ahli Materi}

\begin{tabular}{clccc}
\hline No & \multicolumn{1}{c}{ Aspek Penilaian } & Skor Observasi & $\begin{array}{c}\text { Skor yang } \\
\text { Diharapkan }\end{array}$ & Kelayakan \\
\hline 1 & Kompetensi Dasar & 128 & 144 & $91,43 \%$ \\
2 & Tujuan Pembelajaran & 131 & 144 & $93,57 \%$ \\
3 & Uraian Pendahuluan & 223 & 240 & $92,92 \%$ \\
& Kegiatan Belajar Siswa & 187 & 200 & $93,50 \%$ \\
\hline & Kegiatan Belajar Siswa & $\mathbf{6 6 9}$ & $\mathbf{7 2 8}$ & $\mathbf{9 1 , 8 9 \%}$ \\
\hline
\end{tabular}

Berdasarkan Tabel 3 diketahui rata-rata total penilaian dari tentang media pembelajaran berbasi komputer dengan sebesar 91,89\%. Sesuai dengan skala persentase hasil, tersebut dalam kategori layak untuk digunakan.

\section{c. Hasil Penilaian Guru Mata Pelajaran}

Aspek penilaian untuk ahli multimedia pembelajaran aspek isi materi matapelajaran IPS dan penilaian dilakukan oleh guru pengajar mata pelajaran IPS SDN Tapak Panekan Magetan. Hasil penilaian seperti pada Tabel 4. 
Tabel 4 Hasil Penilaian Guru Mata Pelajaran

\begin{tabular}{clccc}
\hline No & Aspek Penilaian & Skor Observasi & $\begin{array}{c}\text { Skor yang } \\
\text { Diharapkan }\end{array}$ & Kelayakan \\
\hline 1 & Soal Latihan & 131 & 140 & $92,14 \%$ \\
2 & Evaluasi & 168 & 180 & $93,33 \%$ \\
3 & Kunci Jawaban & 150 & 160 & $93,75 \%$ \\
\hline & Jumlah & $\mathbf{4 4 9}$ & $\mathbf{4 8 0}$ & $\mathbf{9 3 , 5 4 \%}$ \\
\hline
\end{tabular}

Berdasarkan Tabel 4 diketahui rata-rata total penilaian dari tentang media pembelajaran berbasis komputer dengan sebesar 93,54\%. Sesuai dengan skala persentase, hasil tersebut dalam kategori layak untuk digunakan.

\section{d. Hasil Uji Kelompok Kecil}

Aspek penilaian uji coba kelompok kecil untuk siswa efek strategi pembelajaran kelompok kecil ini dilakukan untuk mendapatkan masukan, hasil dari simulasi dan uji kelompok kecil digunakan sebagai dasar revisi. Langkah berikutnya adalah uji coba lebih lanjut dengan jumlah siswa yang sesuai dengan kelas sesungguhnya. Hasil uji seperti pada Tabel 5.

\section{Tabel 5 Uji Kelompok Kecil}

\begin{tabular}{|c|c|c|c|c|}
\hline No & Aspek yang Dinilai & $\begin{array}{c}\text { Skor } \\
\text { Observasi }\end{array}$ & $\begin{array}{c}\text { Skor yang } \\
\text { Diharapkan }\end{array}$ & Kelayakan \\
\hline 1 & $\begin{array}{l}\text { E-materi yang telah dikerjakan dapat } \\
\text { menarik perhatian siswa }\end{array}$ & 28 & 28 & $100 \%$ \\
\hline 2 & $\begin{array}{l}\text { E-materi yang telah dikerjakan dapat } \\
\text { memotivasi siswa untuk belajar }\end{array}$ & 25 & 28 & $82,29 \%$ \\
\hline 3 & $\begin{array}{l}\text { E-materi yang telah dipelajari lebih } \\
\text { menarik buku panduan lain bagi } \\
\text { siswa }\end{array}$ & 26 & 28 & $92,86 \%$ \\
\hline 4 & $\begin{array}{l}\text { Modul yang telah dikerjakan dan } \\
\text { dipelajari mempermudah siswa dalam } \\
\text { belajar }\end{array}$ & 27 & 28 & $96,43 \%$ \\
\hline 5 & $\begin{array}{l}\text { E-materi yang telah dikerjakan dapat } \\
\text { menimbulkan sikap belajar siswa }\end{array}$ & 28 & 28 & $100 \%$ \\
\hline 6 & $\begin{array}{l}\text { E-materi yang telah dikerjakan dan } \\
\text { dipelajari menambah pengetahuan } \\
\text { siswa }\end{array}$ & 25 & 28 & $89,29 \%$ \\
\hline \multirow[t]{2}{*}{7} & $\begin{array}{l}\text { Bahasa yang digunakan dalam E- } \\
\text { materi dapat dipahami oleh siswa }\end{array}$ & 25 & 28 & $89,29 \%$ \\
\hline & & 209 & 224 & $93,30 \%$ \\
\hline
\end{tabular}

Berdasarkan Tabel 5, rata-rata total penilaian dari tentang hasil uji kelompok kecil berbasis komputer dengan sebesar 93,30\%. Sesuai dengan skala persentase, hasil tersebut dalam kategori layak untuk digunakan.

\section{Revisi Produk}

Media yang telah selesai dibuat kemudian di uji coba dan selanjutnya divalidasi oleh ahli media pembelajaran. Menurut evaluasi, saran, dan komentar dari ahli media, media yang dikembangkan masih mempunyai beberapa kekurangan dan harus diperbaiki yaitu: (1) beberapa link tidak bisa digunakan dan disarankan untuk diperbaiki kembali; (2) desain pada setiap halaman ketika diklik akan berpindah ke slide berikutnya dan disarankan untuk mengaktifkan fitur on 
mouse clik; (3) Beberapa gambar pada materi belum proposional ukurannya dan disarankan untuk mengganti ukuran gambar menjadi lebih proposional; dan (4) belum ada animasi gerakan pemakanan pahat secara 2 dimensi pada materi kompetensi dasar ke IV pada contoh pemprograman. Pada desain awal terdapat bentuk tulisan yang saling tumpang tindih dengan tulisan yang lain sehingga penyampaian materi kurang dapat diterima. Setelah mendapatkan saran dan masukan dari ahli media dapat menjadi seperti Gambar 4.

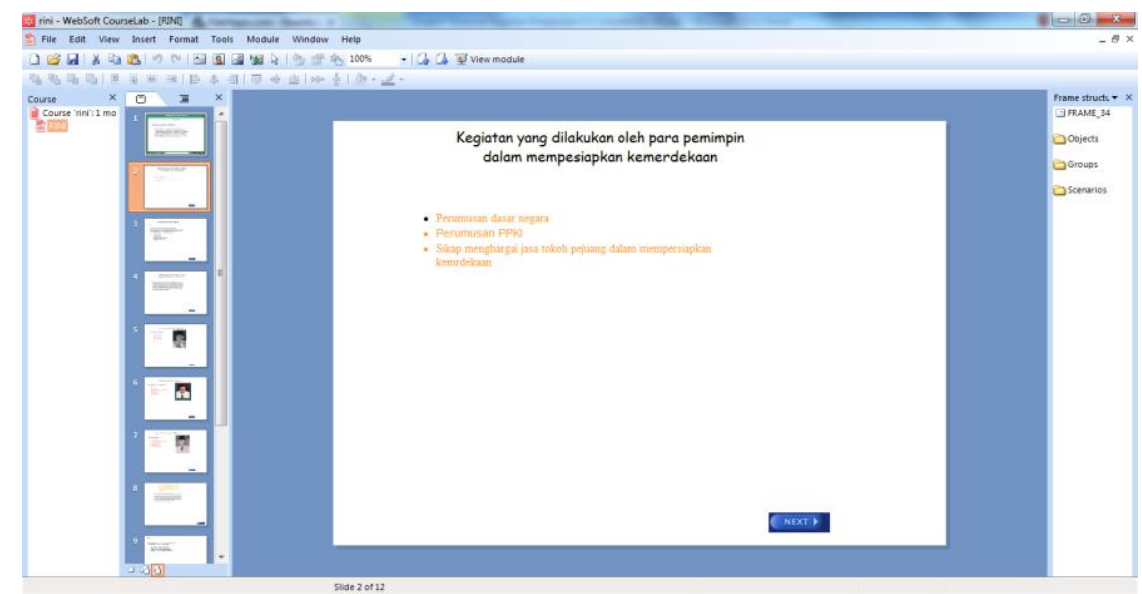

Gambar 4 Tampilan Courselab Awal (Sebelum Direvisi)

Menurut evaluasi, saran dan komentar dari ahli media, media yang dikembangkan masih mempunyai beberapa kekurangan dan harus diperbaiki yaitu terdapat tata tulis yang salah pada slide kompetensi yakni tata tulis pada judul belum ada. Pelaksanaan uji coba kelompok kecil dilakukan kepada 8 siswa Kelas V SDN Tapak Panekan Magetan. Uji coba kelompok kecil dilaksanakan dengan tujuan untuk mengidentifikasi kekurangan produk media pembelajaran. Dari hasil uji coba tersebut diperoleh komentar dari siswa. Menurut komentar dari siswa, secara umum media bagus dan siswa memberikan komentar seharusnya pembelajaran di kelas menggunakan media pembelajaran berbasis komputer agar dapat meningkatkan motivasi siswa.

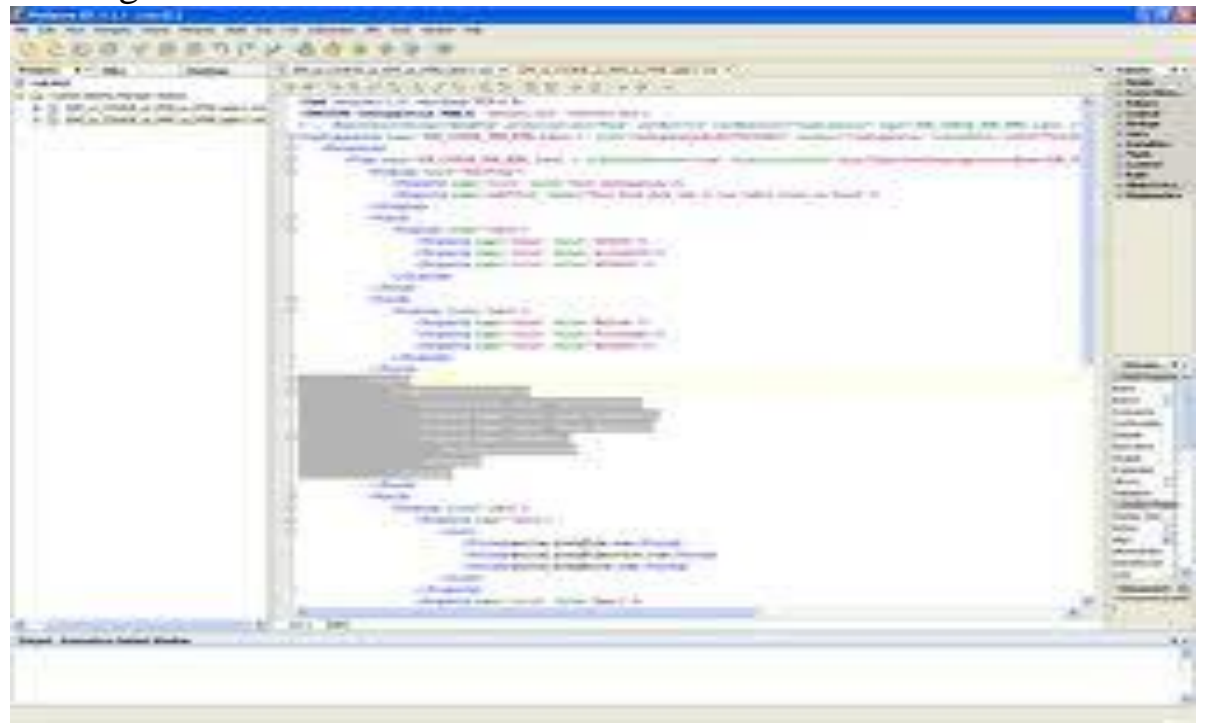

Gambar 5 Tampilan Courselab Setelah Direvisi 


\section{Penerapan Media Pembelajaran}

Kelas $\mathrm{V}$ adalah kelas yang tidak diajar menggunakan media pembelajaran berbasis komputer dan hanya diajar dengan media buku / modul dan papan tulis. Dalam hal ini siswa yang dipilih adalah setengah dari jumlah Kelas V yaitu 8 siswa. Kelas ini diajar dengan metode yang biasa digunakan oleh guru matapelajaran yaitu dengan media papan tulis dan buku / modul. Metode yang digunakan di kelas ini yaitu dengan ceramah, pemberian contoh-contoh program, menjelaskan dengan menulis dan menggambar pada papan tulis, tanya jawab, dan evaluasi.

Kegiatan pembalajaran dalam kelas kontrol yaitu, sebelum pelajaran dimulai, siswa diberikan dahulu soal pretest untuk mengetahui keadaan awal siswa. Kemudian setelah pretest selesai, dilanjutkan dengan pelajaran dengan metode ceramah, pemberian contoh-contoh program, menjelaskan dengan menulis dan menggambar pada papan tulis, dan tanya jawab. Setelah materi pelajaran selesai disampaikan, siswa diberikan soal posttest untuk mengetahui tingkat pemahaman siswa terhadap materi yang telah diberikan. Perbandingan nilai dan kelulusan pretest dan posttest kelas disajikan dalam Tabel 6.

Tabel 6 Perbandingan Nilai Pretest dan Posttest serta Kelulusan Siswa Kelas V

\begin{tabular}{clcc}
\hline No & \multicolumn{1}{c}{ Nilai } & Pretest & Posttest \\
\hline 1 & Nilai terendah & 40 & 50 \\
2 & Nilai tertinggi & 70 & 100 \\
3 & Rata-rata nilai & 60 & 80 \\
4 & Jumlah siswa yang lulus & 1 & 7 \\
5 & Jumlah siswa yang tidak lulus & 7 & 1 \\
\hline
\end{tabular}

Berdasarkan Tabel 6, ada peningkatan rata-rata nilai ratarata kelas antara pretest dan posttest pada kelas kontrol sebesar 80 (75\%). Jumlah siswa yang lulus pada saat prettes sebanyak 1 siswa, sedangkan pada saat posttes sebanyak 7 siswa.

\section{E. PEMBAHASAN}

Media berbasis komputer yang telah dibuat kemudian dilakukan validasi untuk mengetahui kelayakan media tersebut. Setelah media di validasi kemudian media diuji cobakan kepada siswa dalam bentuk uji coba kelompok kecil dan uji coba kelompok besar. Berdasarkan hasil pengembangan media pembelajaran berbasis Courselab untuk matapelajaran IPS pokok bahasan menghargai jasa dan peranan tokoh perjuangan dalam mempersiapkan kemerdekaan Indonesia layak digunakan dan efektif. Hasil pengembangan media pembelajaran berbasis Courselab untuk matapelajaran IPS merupakan strategi dan bertujuan untuk meningkatkan mutu pembelajaran di sekolah (Borg dan Gall, 1989:782). Masalahmasalah praktis yang ditemui dalam lapangan penelitian, digunakan untuk meningkatkan praktik pengajaran di kelas. Sehingga perlu adanya pelatihan keterampilan dalam menguasai teknologi informasi dari seorang guru, guna menginovasi proses pembelajaran di kelas. Sehingga kemampuan guru akan terus berkembang.

Hasil penelitian ini sesuai dengan penelitian Arcana, dkk. (2005) yang menyimpulkan bahwa pembelajaran menggunakan program animasi dapat meningkatkan konsentrasi siswa, terjadi interaksi yang lebih hangat, pembelajaran 
bervariasi sehingga tidak membosankan, mempercepat pemahaman, dan memperlama daya ingat. Siswa di tingkat sekolah dasar dalam konsep perkembangan masuk dalam kategori operasional konkret, sehingga pembelajaran dengan menggunakan banyak gambar, warna, dan gerak. Multimedia berbasis komputer yang mampu menyajikan pesan berupa tulisan, gambar, warna, gerakan dan suara diduga lebih efektif dan menarik untuk proses pembelajaran. CourseLab merupakan piranti lunak penyusun bahan ajar multimedia untuk e-Learning yang powerful dan mudah digunakan. CourseLab menawarkan lingkungan WYSIWYG (What You See Is What You Get) yang bebas dari pemrograman untuk menghasilkan bahan ajar interaktif yang dapat dipublikasikan di internet, Learning Management Systems (LMS), serta CD-ROM (compact disc atau Kaset CD).

E-materi yang telah disajikan oleh guru merupakan rangkuman serangkaian materi yang akan dibahas oleh guru. E-materi ini disajikan dalam betuk elektronik yang memudahkan siswa untuk mengakses materi yang akan diajarkan, sehingga siswa lebih mudah dalam mempelajari materi yang akan dibahas atau dipelajari. Dalam cakupan materi, E-materi ini lebih sempit dibandingkan dengan bahan ajar yang telah disediakan pada umumnya. Sehingga siswa lebih mudah dalam memahami materi yang akan dibahas oleh guru. Courselab ini merupakan alternatif yang dapat digunakan guru untuk pembelajaran kepada siswa. Pada umumnya siswa Kelas V senang dengan hal baru yang sebelumnya mereka belum tahu. Courselab ini membuat pelajaran lebih menjadi variatif dan menyenangkan, sehingga menumbuhkan minat anak untuk mengikuti pembelajaran.

\section{F. KESIMPULAN DAN SARAN}

Berdasarkan hasil penelitian dan pembahasan disimpulkan bahwa prosedur pengembangan media pembelajaran berbasis Courselab adalah: (1) menetapkan mata pelajaran yang akan dikembangkan medianya; (2) melakukan penelitian pendahuluan; (3) pembuatan desain; (4) pengumpulan bahan; (5) mengembangkan bentuk produk; (6) validasi oleh ahli media dan ahli materi; (7) analisis; (8) revisi I / revisi produk awal; (9) evaluasi kelompok kecil; (10) analisis hasil kelompok kecil; (11) revisi II; (12) uji efektivitas / penerapan; dan (13) produk akhir. Proses perancangan produk media pembelajaran pada mata pelajaran IPS pokok bahasan menghargai jasa dan peranan tokoh perjuangan dalam mempersiapkan kemerdekaan indonesia terdapat dua tahap yaitu tahapan perancangan materi dan tahap pengembangan perangkat lunak media.

Tahap perancangan materi Mengoperasikan Media courselab yang dilakukan adalah: (1) identifikasi tujuan; (2) analisis meliputi analisis kebutuhan pemakai dan analisis instruksional; (3) review instruksional; (4) merumuskan kompetensi dasar; dan (5) mengembangkan kriteria. Tahap perancangan pengembangan perangkat lunak yang dilakukan adalah: (1) analisis yang meliputi analisis spesifikasi teknis dan analisis kebutuhan; (2) desain program yang meliputi desain diagram alir, desain interface; (3) implementasi; dan (4) pengujian. Media pembelajaran berbasis komputer pada mata pelajaran IPS dengan Courselab yang dikembangkan layak digunakan untuk mendukung pembelajaran mata pelajaran IPS pokok bahasan menghargai jasa dan peranan tokoh perjuangan dalam mempersiapkan kemerdekaan Indonesia, karena telah 
diuji kelayakannya oleh ahli media dan ahli materi pembelajaran dengan hasil layak.

Berdasarkan hasil pengembangan saran yang disampaikan bagi kepala sekolah adalah mengadakan pelatihan penggunaan teknologi informasi dalam pembelajaran, untuk mengembangkan kemampuan para guru dalam pembuatan media pembelajaran. Bagi guru agar mengadakan inovasi media pembelajaran untuk meningkatkan motivasi dan prestasi belajar siswa. Bagi peneliti lain patut melakukan verifikasi hasil penelitian ini guna mengembangkan teknologi pembelajaran. Agar membuat pengembangan media selanjutnya dengan software Courselab atau software lain yang disesuaikan dengan materi dan metode penelitian. 


\section{DAFTAR RUJUKAN}

Dikti. 2012. Pedoman Pengembangan e-Materi (Online). (http://hibahmpnk.dikti.go.id/wp-content/uploads/downloads/2012/06/Lampiran-4.Pedoman-Pengembangan-e-Materi-2012.pdf, diakses 23 Juli 2011).

Fajar, A. 2009. Portofolio dalam Pembelajaran IPS. Bandung: PT Remaja Rosda Karya.

Nurdin, S. 2005. Model Pembelajaran yang Memperhatikan Keragaman Individu Siswa dalam Kurikulum. Ciputat: Quantum Teaching.

Sapriya. 2009. Pendidikan IPS. Bandung: PT Remaja Rosda Karya.

Slameto. 2010. Belajar dan Faktor-faktor yang Mempengaruhi. Jakarta: Rineka Cipta.

Soebijantoro. 2011. Pembelajaran IPS dan Pendidikan Karakter di Sekolah Dasar. Jurnal Premiere Educandum, 1(1): 13-24.

Sugiyono. 2010. Metode Penelitian Pendidikan. Bandung: Alfabeta.

Sugiyono. 2011. Metode Penelitian Kuantitatif, Kualitatif, dan R\&D. Bandung: Alfabeta.

Susilaningsih, S. 2008. Ilmu Pengetahuan Sosial untuk SD / MI Kelas V. Jakarta Pusat: Departemen Pendidikan Nasional.

Trianto. 2010. Model Pembelajaran Terpadu. Jakarta: Bumi Aksara. 